\title{
KAJIAN PRODUKSI DAN PENDAPATAN USAHATANI KAKAO PADA PROGRAM GERNAS (GERAKAN NASIONAL) KAKAO DI SULAWESI TENGGARA
}

\author{
(Study of Cocoa Farming Production and Income on Gerakan Nasional (GERNAS) Kakao \\ Program in Southeast Sulawesi)
}

\author{
Finayah Akhirul ${ }^{1)}$, Taane La Ola ${ }^{2)}$, Azhar Bafadal ${ }^{2)}$ dan Budiyanto ${ }^{3)}$ \\ ${ }^{1)}$ Program Studi Magister Agribisnis Universitas Halu Oleo \\ Email: finayahakhirul2@gmail.com \\ ${ }^{2) \& 3)}$ Pascasarjana Universitas Halu Oleo \\ ${ }^{3)}$ Email: gadhangku@gmail.com \\ Naskah diterima: 10 April 2018 \\ Naskah direvisi: 12 Juni 2018 \\ Disetujui diterbitkan: 02 September 2018
}

\begin{abstract}
The study was conducted from January to December 2015 in Andomesinggo Village, Besulutu District, Konawe Regency and Lambandia Village, Lambandia District, East Kolaka Regency. The study aims to examine the production and income of cocoa farming after the GERNAS Kakao program has been implemented. Determination of respondents was carried out in census. Data collected were analyzed descriptive quantitatively. The results of the study show that GERNAS Kakao program has been able to significantly increase cocoa farming production. The average production of cocoa farming in Southeast Sulawesi in 2015 was $871.80 \mathrm{~kg}$ per ha while the average production of cocoa beans produced by farming in the GERNAS Kakao program was 1,000.78 $\mathrm{kg}$ per ha. The average cocoa farming income in the GERNAS Kakao program is Rp. 35,920,865, - per ha.
\end{abstract}

Keywords: production, income, GERNAS Kakao program.

Intisari: Studi ini dilaksanakan pada bulan Januari sampai Desember 2015 di Desa Andomesinggo Kecamatan Besulutu Kabupaten Konawe dan Desa Lambandia Kecamtan Lambandia Kabupeten Kolaka Timur. Studi bertujuan mengkaji produksi dan pendapatan usahatani kakao pasca program GERNAS Kakao yang telah dilaksanakan. Penentuan responden dilakukan secara sensus. Data yang dikumpulkan dianalisis secara deskriptif kuantitatif. Hasil studi menunjukkan bahwa program GERNAS Kakao telah mampu meningkatkan produksi usahatani kakao secara signifikan. Rata-rata produksi usahatani kakao di Sulawesi Tenggara tahun 2015 sebesar 871,80 kg per ha sedangkan ratarata produksi biji kakao yang dihasilkan usahatani program GERNAS Kakao sebesar 1.000,78 kg per ha. Rata-rata pendapatan usahatani kakao program GERNAS Kakao sebesar Rp. 35.920.865,-- per ha.

Kata kunci : produksi, pendapatan, program GERNAS Kakao.

\section{PENDAHULUAN}

Kakao merupakan salah satu komoditas andalan perkebunan yang peranannya cukup penting bagi perekonomian nasional, khususnya sebagai penyedia lapangan kerja, sumber devisa, pengembangan wilayah dan pengembangan agroindustri. Indonesia merupakan produsen kakao terbesar ketiga di dunia setelah negara Pantai Gading dan Ghana. Tiga besar negara penghasil kakao adalah Pantai Gading (1.276.000 ton), Ghana (586.000 ton), dan Indonesia (456.000 ton). 
Secara regional, komoditas kakao memiliki peran dan kontribusi yang strategis terhadap perekonomian Sulawesi Tenggara. Jumlah produksi kakao pada tahun 2006 sebesar 194.921 ton, dan memiliki kontribusi terbesar dalam pembentukan PDRB. Sekitar 52 persen total luas perkebunan merupakan perkebunan kakao, maka kegiatan usahatani kakao memegang peranan penting sebagai sumber pendapatan sebagian besar petani di Sulawesi Tenggara. Selain itu, sektor pertanian di Sulawesi Tenggara menyerap tenaga kerja mencapai 127.334 orang petani, atau 15.75 persen dari total tenaga kerja.

Dalam rangka pengembangan usahatani kakao rakyat, pemerintah telah melaksanakan Gerakan Peningkatan Produktivitas dan Mutu Kakao Nasional yang dikenal dengan Gerakan Nasional (GERNAS) Kakao. Harapannya, melalui program Gernas Kakao tahun 2009 sampai dengan 2012 di Provinsi Sulawesi Tenggara adalah dapat meningkatkan minat petani untuk memperbaiki teknis budidaya dan kelembagaan petani kakao Sedangkan tujuan program GERNAS Kakao adalah untuk meningkatkan produksi kakao, pendapatan petani dan pertumbuhan ekonomi daerah. Program GERNAS juga dijadikan momentum untuk kebangkitan industri kakao di Sulawesi Tenggara yang berdayasaing, berkelanjutan dan mewujudkan Indonesia sebagai produsen kakao terbesar di dunia.

Berdasarkan hal tersebut maka untuk mendapatkan gambaran mengenai peran program GERNAS Kakao, khususnya terhadap peningkatan produksi dan pendapatan serta pemasaran usahatani kakao, maka perlu dilakukan studi ini. Tujuan studi ini adalah mengkaji produksi dan pendapatan usahatani kakao pasca program GERNAS Kakao dilaksanakan.

\section{METODOLOGI PENELITIAN}

Studi dilaksanakan di Desa Andomesinggo Kecamatan Besulutu Kabupaten Konawe dan di Desa Lambandia Kecamatan Lambandia Kabupaten Kolaka Timur pada bulan Januari tahun 2015 sampai dengan Desember tahun 2015. Penentuan lokasi penelitian ditentukan secara purposive, dengan pertimbangan bahwa kedua wilayah tersebut dianggap sebagai representasi dari pelaksanaan program GERNAS Kakao.

Populasi dalam studi ini adalah seluruh petani kakao peserta program GERNAS Kakao di Desa Andomesinggo Kecamatan Besulutu Kabupaten Konawe yang berjumlah 13 petani dan di Desa Lambandia Kecamatan Lambandia Kabupaten Kolaka Timur sebanyak 27 petani serta pelaku pemasaran kakao. Penentuan respoden dilakukan secara sensus sehingga jumlah responden sebanyak 40 petani. Variabel yang diamati dalam studi ini adalah karakteristik usahatani kakao yang meliputi: luas lahan usahatani kakao, pola usahatani, jenis-jenis kegiatan pada program GERNAS, jumlah pupuk, jumlah tenaga kerja yang digunakan pada usahatani kakao. Teknik pengumpulan dilakukan dengan metode observasi, wawancara, dan pencatatan atau dokumentasi. Teknik analisis data yang digunakan adalah analisis diskripsi dan analisis pendapatan:

$$
\mathrm{I}=\mathrm{TR}-\mathrm{TC}
$$

Keterangan :

$\mathrm{I}=$ pendapatan usahatani kakao peserta GERNAS Kakao.

$\mathrm{TR}=$ Total Revenue (penerimaan total dari usahatani kakao (Rp)

$\mathrm{TC}=$ Total Cost $($ biaya total dari usahatani kakao $(\mathrm{Rp})$

\section{HASIL DAN PEMBAHASAN}

\section{Luas Lahan Responden}

Lahan sebagai salah satu faktor produksi merupakan pabriknya hasil pertanian mempunyai kontribusi yang cukup besar terhadap produksi usahatani. Sebaran jumlah petani kakao perserta program GERNAS Kakao berdasarkan luas lahan yang diusahakan disajikan pada Tabel 1. 
Tabel 1. Sebaran Jumlah Petani Kakao Perserta Program GERNAS Kakao Berdasarkan Luas Lahan di Sulawesi Tenggara Tahun 2015

\begin{tabular}{|c|c|c|c|}
\hline No. & Luas Lahan (ha) & Jumlah Petani (orang) & Persentase (\%) \\
\hline 1. & $0-2$ & 30 & 75,0 \\
2. & $>2-4$ & 5 & 12,5 \\
3. & $>4$ & 5 & 12,5 \\
\hline & Jumlah & 40 & 100,0 \\
\hline
\end{tabular}

Tabel 1 menunjukkan bahwa sebagian besar petani mengusahakan lahan untuk usahatani kakao antara 0 sampai 2 ha, yaitu sebanyak 75 persen. Pengklasifikasian luas lahan ini merujuk pada panduan teknis budidaya tanaman kakao gerakan peningkatan produksi dan mutu kakao nasional Direktorat Jendral Perkebunan tahun 2010. Luas lahan yang diusahakan sangat penting karena merupakan faktor produksi utama dalam kegiatan usahatani. Ketersediaan luas lahan usahatani tersebut diharapkan dapat meningkatkan hasil produksi kakao dan pada akhirnya akan meningkatkan kesejahteraan petani kakao.

\section{Produksi Usahatani Peserta GERNAS Kakao}

Hasil studi menunjukkan bahwa rata-rata jumlah produksi usahatani kakao peserta program GERNAS Kakao adalah sebesar $2.627 \mathrm{~kg}$ per tahun dan produktivitas sebesar $1.000,78 \mathrm{~kg} / \mathrm{ha}$ sementara itu rata-rata produktivitas usahatani kakao di Sulawesi Tenggara tahun 2015 sebesar 871,80 $\mathrm{kg} / \mathrm{ha}$. Hal ini mengindikasikan bahwa program GERNAS Kakao telah dapat meningkatkan produktivitas usahatani kakao. Produktivitas usahatani kakao yang meningkat secara signifikan tersebut telah menjadikan Kecamatan Andomesinggo Kabupaten Konawe dan Kecamatan Lambandia Kabupaten Kolaka Timur menjadi representasi keberhasilan program GERNAS Kakao di Propinsi Sulawesi Tenggara. Produksi dan produktivitas usahatani kakao disajikan pada Tabel 2.

Tabel 2. Produksi dan Produktivitas Usahatani Kakao di Sulawesi Tenggara Tahun 2015

\begin{tabular}{|l|l|r|r|}
\hline No & \multicolumn{1}{|c|}{ Uraian } & \multicolumn{1}{|c|}{$\begin{array}{c}\text { Usahatani Peserta } \\
\text { Gernas Kakao }\end{array}$} & \multicolumn{1}{|c|}{$\begin{array}{c}\text { Sulawesi } \\
\text { Tenggara }\end{array}$} \\
\hline 1. & Rata-rata produksi kakao (kg/thn) & 2.627 & $162.705,00$ \\
2. & Rata-rata produktivitas (kg/ha/thn) & $1.000,78$ & 871,80 \\
3. & Jumlah petani (orang) & 40 & 169.200 \\
\hline
\end{tabular}

\section{Pendapatan Usahatani Kakao Peserta Program GERNAS Kakao}

Biaya produksi adalah komponen penting dalam suatu usaha yang akan menentukan jumlah input yang digunakan dan output yang dihasilkan. Biaya produksi yang dikeluarkan oleh petani peserta program GERNAS Kakao selama satu kali proses produksi meliputi biaya tetap dan biaya variabel. Biaya tetap adalah biaya yang jumlahnya tetap, tidak mempengaruhi jumlah produksi yang akan dihasilkan. Sedangkan biaya variabel adalah biaya yang sifatnya tergantung pada jumlah produksi yang akan dihasilkan. Biaya tetap pada usahatani kakao penelitian meliputi biaya penyusutan alat dan nilai pajak lahan. Rata-rata biaya tetap, biaya variabel, dan total biaya usahatani kakao peserta program GERNAS Kakao disajikan pada Tabel 3, 4 dan 5.

Tabel 3 menunjukkan bahwa rata-rata biaya tetap pada usahatani kakao peserta program GERNAS Kakao di Sulawesi Tenggara adalah sebesar Rp 458.250,-. Peralatan yang digunakan dalam usahatani kakao terdiri dari parang, cangkul, sprayer, gergaji, karung, terpal, para-para dan gunting pangkas. Variasi nilai penyusutan peralatan dari tiap-tiap usahatani dipengaruhi oleh jumlah dan kualitas peralatan yang digunakan, sedangkan variasi nilai pajak lahan dipengaruhi oleh perbedaan luas lahan dan lokasi lahan usahatani. 
Tabel 3. Rata-rata Biaya Tetap Usahatani Kakao Peserta Program GERNAS Kakao di Sulawesi Tenggara Tahun 2015

\begin{tabular}{|c|l|r|}
\hline No & \multicolumn{1}{|c|}{ Uraian } & \multicolumn{1}{|c|}{ Nilai (Rp) } \\
\hline 1 & Rata-rata nilai penyusutan peralatan & 403.500 \\
2 & Rata-rata nilai pajak lahan & 54.750 \\
\hline \multicolumn{2}{|c|}{ Jumlah } & $\mathbf{4 5 8 . 2 5 0}$ \\
\hline
\end{tabular}

Tabel 4. Rata-Rata Biaya Variabel Usahatani Kakao Peserta Program GERNAS Kakao di Sulawesi Tenggara Tahun 2015

\begin{tabular}{|c|l|r|}
\hline No. & \multicolumn{1}{|c|}{ Uraian } & Nilai (Rp) \\
\hline 1 & Rata-rata biaya tenaga kerja & 1.715 .000 \\
2 & Rata-rata biaya bibit & 4.790 .625 \\
3 & Rata-rata biaya pupuk & 782.250 \\
4 & Rata-rata biaya pestisida & 214.875 \\
\hline \multicolumn{2}{|c|}{ Jumlah } & $\mathbf{7 . 5 0 2 . 7 5 0}$ \\
\hline
\end{tabular}

Tabel 4 menunjukkan bahwa rata-rata biaya variabel usahatani kakao peserta program GERNAS Kakao adalah sebesar Rp 7.502.750,- Variasi jumlah biaya variabel usahatani kakao dikarenakan variasi luas lahan usahatani dan intensitas penggunaan sarana produksi usahatani.

Tabel 5. Rata-rata Total Biaya Usahatani Kakao Peserta Program GERNAS Kakao di Sulawesi Tenggara Tahun 2015

\begin{tabular}{|c|l|r|}
\hline No. & \multicolumn{1}{|c|}{ Uraian } & \multicolumn{2}{|c|}{ Rata-rata Nilai (Rp) } \\
\hline 1 & Rata-rata biaya Tetap & 458.250 \\
2 & Biaya Variabel & 7.502 .750 \\
\hline \multicolumn{2}{|c|}{ Jumlah } & $\mathbf{7 . 9 6 1 . 0 0 0}$ \\
\hline
\end{tabular}

Tabel 5 menunjukkan bahwa rata-rata total biaya usahatani kakao peserta program GERNAS Kakao adalah sebesar Rp 7.961.000,-. Perbedaan penggunaan biaya usahatani kakao dikarenakan oleh perbedaan luas lahan dan perbedaan penggunaan input produksi.

\section{Penerimaan dan pendapatan Usahatani peserta GERNAS Kakao}

Penerimaan adalah perkalian antara produksi usahatani dengan harga jual produksi kakao, sedangkan pendapatan merupakan selisih antara total penerimaan dengan total biaya usahatani. Ratarata pendapatan usahatani kakao peserta program GERNAS Kakao disajikan pada Tabel 6.

Tabel 6. Rata-rata Pendapatan Usahatani Kakao Peserta Program GERNAS Kakao di Sulawesi Tenggara Tahun 2015

\begin{tabular}{|l|l|r|r|}
\hline No & \multicolumn{1}{|c|}{ Uraian } & Per Usahatani & \multicolumn{1}{|c|}{ Per Hektar } \\
\hline 1. & Rata-rata produksi $(\mathrm{Kg})$ & 2.627 & 1.000 \\
2. & Rata-rata harga produksi $(\mathrm{Rp} / \mathrm{Kg})$ & 38.375 & 38.375 \\
3. & Rata-rata biaya usahatani $(\mathrm{Rp})$ & 7.961 .000 & 2.627 .753 \\
4. & Rata-rata penerimaan $(\mathrm{Rp})$ & 101.190 .125 & 38.548 .619 \\
5. & Rata-rata pendapatan $(\mathrm{Rp})$ & 93.229 .125 & 35.920 .865 \\
\hline
\end{tabular}


Tabel 6 menunjukkan bahwa rata-rata pendapatan per usahatani kakao Peserta Program GERNAS Kakao sebesar Rp. 93.229.125 per tahun, sedangkan per hektarnya adalah sebesar Rp. 35.920.865,atau setiap hektarnya adalah sebesar Rp 2.993.405, 42.

\section{KESIMPULAN DAN SARAN}

Berdasarkan uraian pada pembahasan, maka dapat disimpulkan bahwa 1) program GERNAS Kakao mampu meningkatkan produksi usahatani kakao secara signifikan, dan 2) rata-rata pendapatan usahatani kakao peserta program GERNAS Kakao di Provinsi Sulawesi Tenggara adalah sebesar Rp. Rp. 35.920.865,- per hektar selama setahun. Selanjutnya, kepada pemerintah diharapkan dapat mempertahankan dan mengembangkan program GERNAS Kakao, karena program ini dapat meningkatkan produksi dan pendapatan usahatani kakao.

\section{DAFTAR PUSTAKA}

Badan Pusat Statistik. 2014. Statistik Perkebunan 2013. Badan Pusat Statistik Sulawesi Tenggara. Kendari.

Tenggara. Kendari. 2017. Sulawesi Tenggara Dalam Angka 2016. Badan Pusat Statistik Sulawesi

Direktorat Jendral Perkebunan. 2010. Panduan Teknis Budiadaya Tanaman Kakao, Gerakan Peningkatan Produksi dan Mutu Kakao Nasional. Direktorat Jenderal Perkebunan. Jakarta.

Dinas Perkebunan dan Hortikultura Provinsi Sulawesi Tenggara dan Universitas Halu Oleo. 2011. Kajian Aspek Sosial Ekonomi GERNAS Kakao Bagi Petani di Sulawesi Tenggara. Fakultas Pertanian Universitas Halu Oleo dan Dinas Perkebunan dan Hortikultura Provinsi Sulawesi Tenggara. Kendari. 2002. Program Rehabilitasi dan Peremajaan Kakao dengan Pola Sambung Samping. Dinas Perkebunan dan Hortikultura Provinsi Sulawesi Tenggara. Kendari. . 2008. Laporan Komoditi Kakao Tahunan. Dinas Perkebunan dan Hortikultura

Provinsi Sulawesi Tenggara. Kendari. 2017. Statistik Perkebunan Tahun 2016. Dinas Perkebunan dan Hortikultura

Provinsi Sulawesi Tenggara. Kendari. 